\title{
SEXUAL HEALTH AMONG PORTUGUESE ADOLESCENTS: CHANGES IN A 8 YEAR PERIOD (2002-2010)
}

\author{
Lúcia Ramiro, Margarida Gaspar de Matos, Marta Reis \\ Technical University of Lisbon (UTL), \\ CMDT \& Aventura Social Project, Cruz Quebrada, Portugal \\ E-mail: lisramiro@sapo.pt, mmatos@fmh.utl.pt, reispsmarta@gmail.com
}

\begin{abstract}
Recently HIV is falling in a significant number of countries, partly due to the adoption of preventive behaviors, which demonstrates that decreasing sexual transmission of HIV is possible. The aim of this research was to analyze preventive sexual behavior in Portuguese adolescents, including information and attitudes about HIVI AIDS, and assessing whether they changed from 2002 to 2010. Data were collected through a self-administered questionnaire from the Portuguese sample of the Health Behaviour in School-aged Children (HBSC), a collaborative WHO study. The study provided national representative data of 10587 Portuguese adolescents, randomly chosen from those attending 8th and 10th grades and the opportunity to examine trends in sexual behaviour on a national level. In terms of preventive behaviours, results showed an increasing trend regarding the percentage reporting first sexual intercourse at 14 years old or more and condom use at last sexual intercourse and a stabilized trend concerning having had sexual intercourse and contraceptive pill use. Nevertheless, in terms of information and attitudes about HIVIAIDS, results showed a systematic decreasing trend.
\end{abstract}

Key words: adolescents, attitudes, information, preventive behaviours, sex education.

\section{Introduction}

According to UNAIDS (2011), at the end of 2010 there were about 34 million people living with HIV infection in the world and $42 \%$ of the newly HIV/AIDS infected occur in young people aged between 15 and 24 years old.

In Portugal, according to the latest available report from the national monitoring center of sexually transmitted diseases (CVEDT, 2011), there was a proportional increase in the number of cases of heterosexual transmission among the 20-49 year old cohort (which means that some were infected during adolescence), confirming the epidemiological pattern recorded annually since 2000 (CVEDT, 2011).

Recently HIV is falling in a significant number of countries, partly due to the adoption of preventive behaviors, which demonstrates that decreasing sexual transmission of HIV is possible. In fact, literature claims that prevention is the best way to control STIs and condom use is generally accepted as the best preventive behavior regarding STIs among sexually active individuals. Nevertheless, young people still are a major concern as their risk for infections is higher than in adults (UNAIDS, 2010), mainly because of their physical, emotional and cognitive immaturity. In addition, young people are particularly vulnerable to STIs and subsequent health problems because they don't have the necessary information regarding STIs prevention, are more reluctant to search for information and are more frequently involved in risky sexual behaviors, such as engaging in sex 
without condom and having multiple sequential partners (UNAIDS, 2008). For those reasons, early sexual initiation has been identified as a crucial indicator for sexual health (CDC, 2010; UNAIDS, 2010; WHO, 2010).

Though there are several HIV prevention interventions currently being put into practice, the majority aren't theory-based and instead focus (almost) completely on information and do not invest in training motivation and behavioral skills (Currie, Hurrelmann, Settertobulte, Smith, \& Todd, 2000). As a consequence, these interventions do not have a relevant impact on young people's behaviors. Therefore, it is critically important to implement interventions based on theories that have empirically demonstrated to decrease sexual risk behaviors (Currie, Hurrelmann, Settertobulte, Smith, \& Todd, 2000).

According to literature, if young people have information and motivation on preventive sexual behaviors, they may change their attitudes and their behaviors (Belo, \& Silva, 2004; Synovitz, Herbert, Kelley, \& Carlson, 2002).

The information-motivation behavioral skills (IMB) model (Bandura, 1989) has been validated over the years with several populations. According to this model, HIV prevention information, motivation, and behavioral skills are fundamental determinants of HIV preventive behaviors. As for information, it contemplates information regarding HIV transmission and prevention; as for motivation, it refers to the engagement in HIV preventive behaviors, as well as personal motivation (positive attitudes towards the performance of HIV preventive actions) and social motivation (perceived social support for engaging in these actions); and as for behavioral skills, it refers to the specific skills one needs so as to perform HIV preventive actions, which includes the sense of self-efficacy for doing them (Bandura, 1989;1994; Fisher, \& Fisher, 1992; 1993). Hence, according to the IMB model there are three prerequisites to have HIV preventive behaviors: information, motivation and behavioral skills. The three of them together determine individuals' ability to have preventive behaviors.

According to WHO's recommendations (2008), in the absence of an effective cure for HIV/ AIDS, and taking into account the particular epidemiology of the disease, the prevention of AIDS depends largely on the adoption and maintenance of safe behaviors, therefore the educational strategies that modify or eliminate risk behaviors are central to prevent the spread of this pandemic.

Since adolescence is the stage of transition between childhood and adulthood, and this stage is characterized by a plasticity and vulnerability of the personality, adolescents are naturally more prone to understand the concepts that will lead them to a healthier physical, psychological and sexual maturity. It is crucial that they realize that their sexuality can be experienced in a healthy and happy way, and that to protect from STIs, including HIV/AIDS, they have to use condoms always (for it is the only way of protection against HIV/AIDS and other STIs among sexually active individuals) (Matos, 2008).

As such, it is crucial to educate young people before they engage in sexual behaviors as it is easier to adopt than change behaviors. To be successful, the prevention must involve not only working on information but also motivation and behavioral skills (Eurostat, 2012; UNFPA, 2005).

In order for a IMB-based model HIV intervention to be effective for Portuguese adolescents, their specific information, motivation and behavior skills deficits must be addressed, which requires identifying them previously to intervention. As a result, this article aims to analyze preventive sexual behavior in Portuguese adolescents, including information and attitudes about HIV/AIDS, and assessing whether they have changed and how they have changed from 2002 to 2010.

This analysis is important in terms of surveillance and epidemiological trends of risky sexual behaviors. Further, study findings provide insights into the relations between adolescents' sexual behaviors and sex education, which is likely to moderate the effects of individual risk factors on sexual behaviors.

\section{Methodology of Research}

\section{General Background of Research}

Data were collected through a self-administered questionnaire from the Portuguese sample of the Health Behavior in School-aged Children (HBSC) study of 2002, 2006 and 2010 (Currie et al., 2000; 
Matos et al., 2003; 2006). The HBSC study has been conducted every four years in 43 countries in collaboration with the World Health Organization (WHO) with the aim to describe young people's health and health behaviors as well as understand how they relate to different social contexts.

\section{Sample of Research}

The sampling unit used in this survey was the class. The 139 schools in the sample were randomly selected from the official national list of public schools (Ministério da Educação, 2013), stratified by region. In each school, classes were randomly selected in order to meet the required number of students for each grade, according to the international research protocol (Currie et al., 2000).

The study provided national representative data of 10587 Portuguese adolescents, randomly chosen from those attending 8th and 10th grade of high school and the opportunity to examine trends in sexual behavior on a national level. The sample included $52.7 \%$ girls and $47.3 \%$ males, whose mean age was 15.04 years (standard deviation 1.33). The majority of adolescents were of Portuguese nationality $(93.8 \%), 52.1 \%$ attended the 8 th grade and $47.9 \%$ attended the 10 th grade and were distributed proportionally by all the educational Portuguese regions (North, Center, Lisbon and Tagus Valley, Alentejo and the Algarve) in the mainland (see table 1).

Table 1. Socio demographic characteristics for the total sample.

\begin{tabular}{lcccccccc}
\hline & \multicolumn{2}{c}{$\begin{array}{c}2002 \\
(\mathbf{N}=3762)\end{array}$} & \multicolumn{2}{c}{$\begin{array}{c}2006 \\
(\mathbf{N}=3331)\end{array}$} & \multicolumn{2}{c}{$\begin{array}{c}2010 \\
(\mathbf{N}=3494)\end{array}$} & \multicolumn{2}{c}{$\begin{array}{c}\text { Total1 } \\
(\mathbf{N}=10587)\end{array}$} \\
\hline Gender & $\mathbf{N}$ & $\%$ & $\mathbf{N}$ & $\%$ & $\mathbf{N}$ & $\%$ & $\mathbf{N}$ & $\%$ \\
\hline Male & 1806 & 48.0 & 1579 & 47.4 & 1622 & 46.4 & 5007 & 47.3 \\
Female & 1956 & 52.0 & 1752 & 52.6 & 1872 & 53.6 & 5580 & 52.7 \\
Grade & & & & & & & & \\
8th grade & 2181 & 58.0 & 1740 & 52.2 & 1594 & 45.6 & 5515 & 52.1 \\
10th grade & 1581 & 42.0 & 1591 & 47.8 & 1900 & 54.4 & 5072 & 47.9 \\
Nationality & & & & & & & & \\
Portuguese & 3382 & 93.3 & 3101 & 94.1 & 3145 & 94.2 & 9628 & 93.9 \\
African + Brazilian & 116 & 3.2 & 111 & 3.4 & 94 & 2.8 & 321 & 3.1 \\
Other & 127 & 3.5 & 82 & 2.5 & 101 & 3.0 & 310 & 3.0 \\
& & & & & & & & \\
& $M$ & $S D$ & $M$ & $S D$ & $M$ & $S D$ & $M$ & $S D$ \\
Age & 15.12 & 1.35 & 15.07 & 1.34 & 14.94 & 1.30 & 15.04 & 1.33 \\
\hline
\end{tabular}

${ }^{1}$ The total numbers differ considering that some subjects have not replied to some variables.

Instrument and Procedures

In the questionnaire, which covered a wide range of questions about behaviors and lifestyles in adolescence, it was selected issues that relate to socio-demographic characteristics, sexual behavior, information regarding HIV/AIDS transmission / prevention and attitudes towards people living with HIV/AIDS. Further information about the survey procedures can be found elsewhere (Currie et al., 2012; Roberts et al., 2009).

Sexual behaviour. Sexual behaviors were measured through the following behaviors - ever had sexual intercourse (Yes/No), age of first sexual intercourse (11 years or less/12-13 years/14 years or more), male condom use at last sexual intercourse (Yes/No), and contraceptive pill use at last sexual intercourse (Yes/No).

Information regarding HIV/AIDS transmission/prevention. Participants were asked to respond to nine statements about HIV/AIDS transmission/prevention (Currie, Samdal, Boyce \& Smith, 2001). The Portuguese version of the scale was used (Matos, et al., 2011). Young people were asked 
to respond to nine statements about HIV/AIDS transmission/prevention: 1."it is possible to become infected with HIV/AIDS by sharing needles"; 2. "it is possible to become infected with HIV/Aids

from coughing and sneezing"; 3."an $\boldsymbol{H I V}$-infected pregnant woman may pass the virus to her baby"; 4. "it is possible to become infected with HIV/AIDS by hugging someone infected"; 5."the oral contraceptive can protect against HIV/AIDS infection"; 6."it is possible to become infected with HIV/ AIDS by engaging in unprotected sexual intercourse with someone just once"; 7."someone who looks healthy can be HIV infected"; 8. "it is possible to become infected with HIV/AIDS by sharing a glass, fork/spoon"; 9."it is possible to become infected with HIV/AIDS by blood transfusion in a Portuguese hospital". Items were rated on a three response options $(1=$ Yes, $2=$ No and $3=\mathrm{I}$ do not know). Only responses that showed correct information scored and so final scores ranged from 0 to 9 , with high scores suggesting more information. These items were shown to have adequate reliability (Cronbach's alpha of 0.81).

Attitudes towards HIV/AIDS - infected people. Young people were asked to respond to five statements about attitudes towards HIV-infected people (Currie, Samdal, Boyce \& Smith, 2001). The Portuguese version of the scale was used (Matos, et al., 2011). Participants were asked to respond to: 1. "I wouldn't be a friend of someone if he had AIDS", 2. "Adolescents with AIDS should be allowed to go to school", 3. "I would sit near an infected student in classroom", 4. "I would visit a friend if he or she had AIDS" and 5. "HIV infected people should live apart of the rest of people". Items were rated on a 3-point rating scale ( $1=$ disagree to $3=$ agree). After recoding items 1 and 5, final scores ranged from 5 to 15 , with high scores suggesting more tolerant attitudes. These items were shown to have adequate reliability (Cronbach's alpha of 0.76 ).

This study had the approval of a scientific committee, an ethical national committee and the national commission for data protection and followed strictly all the guidelines for human rights protection.

\section{Data Analysis}

Analyses and statistical procedures were carried out in the Statistical Package for Social Sciences program (SPSS, version 20.0 for Windows). Overall, structured self-reported questionnaires were responded by 10587 participants. The total numbers differed considering that some participants have not replied to some questions. Means, standard deviations, frequencies and other descriptive statistics were performed to characterize the sample. The level of statistical significance was set at $\mathrm{p}<0.001$ due to the size of the sample.

Chi-square tests were used to examine sexual behaviors, information regarding HIV/AIDS transmission/prevention and attitudes towards HIV/AIDS - infected people, according to base year. Upward or downward trends were determined through the comparison of the module that corresponded to an adjusted residual $\geq|1.9|$. ANOVA tests were used to examine final scores according to base year and upward or downward trends were determined through Scheffe post hoc tests. Analyses were controlled for gender, age and school grade.

\section{Results of Research}

Table 2 shows trends in sexual behaviour between 2002 and 2010.

There was no statistically significant difference for the percentage of young people reporting ever having had sexual intercourse $(23.7 \%$ in $2002,22.7 \%$ in 2006 and $21.8 \%$ in 2010$)\left(\chi^{2}(2)=\right.$ $3.84 ; \mathrm{p}=0.147)$.

Among those who were sexually active, an overall increase was observed in age of first sexual intercourse $\left(\chi^{2}(4)=57.46 ; \mathrm{p}<0.001\right)$ peaking in $2006(56.8 \%$ in 2002 versus $71.1 \%$ in 2006 , and $68.9 \%$ in 2010 at 14 years or more). From 2002 to 2006 a decreasing trend was observed among those who initiated at 11 years or less as well as among those who initiated between 12 and 13. In both cases it stabilized from 2006 onwards.

Among those who were sexually active, $82.5 \%$ reported that they or their partner used a condom the last time they had engaged in sexual intercourse, which means that about $18 \%$ are currently at high risk. Considering the three cycles of the study, an increase was observed $\left(\chi^{2}(2)=31.36\right.$; $<<$ 
$0.001)$, which was especially strong between 2002 and 2006 (71.8\% in 2002, 81.1\% in 2006 and $82.5 \%$ in 2010).

There was no statistical significant difference neither for the percentage of young people reporting having used the contraceptive pill at last sexual intercourse $(40.0 \%$ in 2002, 47.1\% in 2006 and $53.5 \%$ in 2010$)\left(\chi^{2}(2)=11.60 ; \mathrm{p}=0.003\right)$.

Table 2. Differences between 2002, 2006 and 2010 for questions about sexual behaviour.

\begin{tabular}{|c|c|c|c|c|c|c|c|c|c|c|}
\hline & \multicolumn{2}{|c|}{2002} & \multicolumn{2}{|c|}{2006} & \multicolumn{2}{|c|}{2010} & \multicolumn{2}{|c|}{ Total1 } & \multirow{2}{*}{$\chi^{2}$} & \multirow{2}{*}{$\mathrm{p}$} \\
\hline & $\mathrm{N}$ & $\%$ & $\mathbf{N}$ & $\%$ & N & $\%$ & $\mathrm{~N}$ & $\%$ & & \\
\hline Sexual intercourse & & & & & & & & & 3.835 & 0.147 \\
\hline Yes & 862 & 23.7 & 723 & 22.7 & 748 & 21.8 & 2333 & 22.7 & & \\
\hline \multirow[t]{4}{*}{ No } & 2772 & 76.3 & 2464 & 77.3 & 2688 & 78.2 & 7924 & 77.3 & & \\
\hline & \multicolumn{8}{|c|}{ Young people who have had sexual intercourse } & & \\
\hline & \multicolumn{2}{|c|}{2002} & \multicolumn{2}{|c|}{2006} & \multicolumn{2}{|c|}{2010} & \multicolumn{2}{|c|}{ Total1 } & \multirow{2}{*}{$\chi^{2}$} & \multirow{2}{*}{$\mathrm{p}$} \\
\hline & N & $\%$ & $\mathbf{N}$ & $\%$ & N & $\%$ & N & $\%$ & & \\
\hline $\begin{array}{l}\text { Age of 1st sexual } \\
\text { intercourse }\end{array}$ & & & & & & & & & 57.456 & 0.000 \\
\hline 11 years or less & 143 & 17.2 & 68 & 9.7 & 54 & 7.4 & 265 & 11.7 & & \\
\hline $12-13$ years & 217 & 26.1 & 134 & 19.2 & 173 & 23.7 & 524 & 23.2 & & \\
\hline 14 or more & 473 & 56.8 & 497 & 71.1 & 504 & 68.9 & 1474 & 65.1 & & \\
\hline $\begin{array}{l}\text { Condom use at last } \\
\text { sexual intercourse }\end{array}$ & & & & & & & & & 31.364 & 0.000 \\
\hline Yes & 595 & 71.8 & 555 & 81.1 & 591 & 82.5 & 1741 & 78.1 & & \\
\hline No & 234 & 28.2 & 129 & 18.9 & 125 & 17.5 & 488 & 21.9 & & \\
\hline $\begin{array}{l}\text { Pill use at last sexual } \\
\text { intercourse }\end{array}$ & & & & & & & & & 11.599 & 0.003 \\
\hline Yes & 118 & 40.0 & 156 & 47.1 & 183 & 53.5 & 457 & 47.2 & & \\
\hline No & 177 & 60.0 & 146 & 52.9 & 159 & 46.5 & 511 & 52.8 & & \\
\hline
\end{tabular}

${ }^{1}$ The total numbers differ considering that some subjects have not replied to some variables.

In bold - values that correspond to an adjusted residual $\geq|1.9|$

Table 3 shows trends in information regarding HIV/AIDS transmission / prevention between 2002 and 2010 for the total sample.

According to results, from 2002 to 2010, young people more often said that coughing, sneezing and hugging someone infected with HIV/AIDS could be a means of transmission and that the contraceptive pill could protect a woman from being infected. In 2010, young people less often claimed that a person could become infected with HIV/AIDS if he/she used a needle and / or a syringe already used by an infected person, that an infected pregnant woman could infect her baby and that one could become infected by engaging in unprotected sexual intercourse with someone just once. Results showed a decreasing trend in five out of nine statements concerning information regarding HIV/AIDS transmission/prevention.

A slight increase in information was observed peaking in 2006 but decreasing substantially in 2010 in two of the remaining statements: respondents disagreed that the oral contraceptive could protect against HIV/AIDS infection $\left(\chi^{2}(4)=102.058 ; p<0.001\right)$ and agreed that someone who looked healthy could be HIV infected $\left(\chi^{2}(4)=151.145 ; p<0.001\right)(9.8 \%$ in $2002,11.3 \%$ in 2006 
and $13.5 \%$ in 2010 ; and $76.0 \%$ in $2002,78.2 \%$ in 2006 and $67.0 \%$ in 2010 , respectively).

The only statement with which young people presented more accurate information was about the impossibility of becoming infected with HIV/AIDS by blood transfusion in Portugal.

Overall, from 2002 to 2010 there was a systematic decrease in information regarding HIV/ AIDS transmission/prevention. The Post-hoc comparisons by the Scheffe method indicated that young people reported having more information regarding HIV/AIDS transmission/prevention in 2002 than in 2006 and in 2010.

Table 3. Differences between 2002, 2006 and 2010 for information regarding HIV/ AIDS transmission/prevention for the total sample.

\begin{tabular}{|c|c|c|c|c|c|c|c|c|c|c|}
\hline & & & & & & & & & $\varkappa^{2}$ & \\
\hline & $\mathbf{N}$ & $\%$ & $\mathrm{~N}$ & $\%$ & $\mathrm{~N}$ & $\%$ & $\mathbf{N}$ & $\%$ & $\chi$ & $\rho$ \\
\hline $\begin{array}{l}\text { It is possible to become } \\
\text { infected with HIVIAIDS } \\
\text { by sharing needles }\end{array}$ & & & & & & & & & 360.893 & 0.000 \\
\hline Yes & 3500 & 94.1 & 2831 & 89.8 & 2558 & 79.9 & 8889 & 88.2 & & \\
\hline I do not know & 128 & 3.4 & 249 & 7.9 & 484 & 15.1 & 861 & 8.6 & & \\
\hline No & 93 & 2.5 & 74 & 2.3 & 159 & 5.0 & 326 & 3.2 & & \\
\hline $\begin{array}{l}\text { It is possible to become } \\
\text { infected with HIVIAids } \\
\text { from coughing and } \\
\text { sneezing }\end{array}$ & & & & & & & & & 137.908 & 0.000 \\
\hline Yes & 454 & 12.2 & 445 & 13.9 & 464 & 14.6 & 1363 & 13.5 & & \\
\hline I do not know & 732 & 19.7 & 753 & 23.5 & 972 & 30.5 & 2457 & 24.3 & & \\
\hline No & 2525 & 68.0 & 2002 & 62.6 & 1751 & 54.9 & 6278 & 62.2 & & \\
\hline $\begin{array}{l}\text { An HIV-infected pregnant } \\
\text { woman may pass the } \\
\text { virus to her baby }\end{array}$ & & & & & & & & & 438.626 & 0.000 \\
\hline Yes & 3298 & 89.0 & 2564 & 80.2 & 2194 & 68.8 & 8056 & 79.8 & & \\
\hline I do not know & 302 & 8.1 & 485 & 15.2 & 792 & 24.9 & 1579 & 15.7 & & \\
\hline No & 106 & 2.9 & 150 & 4.7 & 201 & 6.3 & 457 & 4.5 & & \\
\hline $\begin{array}{l}\text { It is possible to become } \\
\text { infected with HIVIAIDS } \\
\text { by hugging someone } \\
\text { infected }\end{array}$ & & & & & & & & & 464.847 & 0.000 \\
\hline Yes & 114 & 3.1 & 175 & 5.5 & 254 & 8.0 & 543 & 5.4 & & \\
\hline I do not know & 234 & 6.3 & 349 & 10.9 & 671 & 21.1 & 1254 & 12.4 & & \\
\hline No & 3352 & 90.6 & 2673 & 83.6 & 2262 & 71.0 & 8287 & 82.2 & & \\
\hline $\begin{array}{l}\text { The oral contraceptive } \\
\text { can protect against HIVI } \\
\text { AIDS infection }\end{array}$ & & & & & & & & & 102.058 & 0.000 \\
\hline Yes & 361 & 9.8 & 361 & 11.3 & 429 & 13.5 & 1151 & 11.4 & & \\
\hline I do not know & 905 & 24.5 & 694 & 21.7 & 957 & 30.1 & 2556 & 25.4 & & \\
\hline No & 2432 & 65.8 & 2145 & 67.0 & 1792 & 56.4 & 6369 & 63.2 & & \\
\hline $\begin{array}{l}\text { It is possible to become } \\
\text { infected with HIVI } \\
\text { AIDS by engaging in } \\
\text { unprotected sexual } \\
\text { intercourse with } \\
\text { someone just once }\end{array}$ & & & & & & & & & 258.596 & 0.000 \\
\hline Yes & 3251 & 87.9 & 2766 & 86.7 & 2414 & 76.1 & 8431 & 83.8 & & \\
\hline I do not know & 260 & 7.0 & 273 & 8.6 & 581 & 18.3 & 1114 & 11.1 & & \\
\hline No & 187 & 5.1 & 150 & 4.7 & 177 & 5.6 & 514 & 5.1 & & \\
\hline
\end{tabular}




\begin{tabular}{|c|c|c|c|c|c|c|c|c|c|c|}
\hline & \multicolumn{2}{|c|}{2002} & \multicolumn{2}{|c|}{2006} & \multicolumn{2}{|c|}{2010} & \multicolumn{2}{|c|}{ Total $^{1}$} & \multirow{2}{*}{$\chi^{2}$} & \multirow{2}{*}{$p$} \\
\hline & $\mathrm{N}$ & $\%$ & $\mathrm{~N}$ & $\%$ & $\mathrm{~N}$ & $\%$ & $\mathbf{N}$ & $\%$ & & \\
\hline $\begin{array}{c}\text { Someone who looks } \\
\text { healthy can be HIV } \\
\text { infected }\end{array}$ & & & & & & & & & 151.145 & 0.000 \\
\hline Yes & 2800 & 76.0 & 2485 & 78.2 & 2124 & 67.0 & 7409 & 73.8 & & \\
\hline I do not know & 572 & 15.5 & 517 & 16.3 & 796 & 25.1 & 1885 & 18.8 & & \\
\hline No & 313 & 8.5 & 177 & 5.6 & 251 & 7.9 & 741 & 7.4 & & \\
\hline
\end{tabular}

\begin{tabular}{|c|c|c|c|c|c|c|c|c|c|c|c|}
\hline $\begin{array}{l}\text { It is possible to become } \\
\text { infected with HIV/AIDS } \\
\text { by sharing a glass, fork/ } \\
\text { spoon }\end{array}$ & & & & & & & & & & 19.840 & 0.000 \\
\hline Yes & 798 & 21.5 & 726 & 22.8 & 701 & 22.1 & 2225 & & 22.1 & & \\
\hline I do not know & 922 & 24.9 & 931 & 29.2 & 1139 & 35.9 & 2992 & & 29.7 & & \\
\hline No & 1986 & 53.6 & 1534 & 48.1 & 1330 & 42.0 & 4850 & & 48.2 & & \\
\hline $\begin{array}{l}\text { It is possible to become } \\
\text { infected with HIVIAIDS } \\
\text { by blood transfusion in a } \\
\text { Portuguese hospital }\end{array}$ & & & & & & & & & & 48.894 & 0.000 \\
\hline Yes & 3138 & 84.7 & 2060 & 64.6 & 1747 & 55.0 & 6945 & & 9.0 & & \\
\hline I do not know & 415 & 11.2 & 788 & 24.7 & 1043 & 32.8 & 2246 & & 2.3 & & \\
\hline \multirow[t]{3}{*}{ No } & 153 & 4.1 & 339 & 10.6 & 387 & 12.2 & 879 & & 8.7 & & \\
\hline & \multicolumn{2}{|c|}{2002} & \multicolumn{2}{|c|}{2006} & \multicolumn{2}{|c|}{2010} & \multicolumn{2}{|c|}{ Total } & & & $\begin{array}{c}\text { Scheffe } \\
\text { post }\end{array}$ \\
\hline & M & $S D$ & M & SD & M & SD & M & SD & $\mathrm{F}$ & $p$ & hocs $^{2}$ \\
\hline Total scale & 6.30 & 1.70 & 6.16 & 2.08 & 5.32 & 2.60 & 5.95 & 2.18 & 196.117 & 0.000 & $a<b<c$ \\
\hline
\end{tabular}

${ }^{1}$ The total numbers differ considering that some participants have not replied to some variables.

${ }^{2}$ The $a, b, c$ and $<>$ signs - represent statistically significant differences within groups for $p<0.050$ by the Scheffe POSTHOC method. In bold - values that correspond to an adjusted residual $\geq|1.9|$

Table 4 shows trends in attitudes towards HIV/AIDS infected people between 2002 and 2010 for the total sample.

It was found that in 2002 young people agreed more often that adolescents with AIDS should be allowed to go to school, that they would be able to attend a class next to a colleague infected with HIV/AIDS, and that they would visit a friend that was infected, and more adolescents disagreed that HIV infected people should live apart of the rest of the people.

Overall, from 2002 to 2010, results showed a decreasing trend in four out of five statements concerning positive attitudes towards people with HIV/AIDS: adolescents with AIDS should be allowed to go to school $\left(\chi^{2}(4)=72.083 ; p<0.001\right)$; I would sit near an infected student in classroom $\left(\chi^{2}(4)=117.797 ; \mathrm{p}<0.001\right)$; I would visit a friend if he or she had AIDS $\left(\chi^{2}(4)=201.713 ; \mathrm{p}<0.001\right)$; and HIV infected people should live apart of the rest of the people $\left(\chi^{2}(4)=144.506 ; p<0.001\right)$. The Post-hoc comparisons by the Scheffe method indicated that young people reported having more positive attitudes towards people with HIV/AIDS in 2002 than in 2006 and in 2010.

Separate analyses for control variables (gender, age and school grade) were conducted regarding all variables under study. The same patterns were found in each of the three survey years concerning a) information regarding HIV/AIDS transmission / prevention, b) attitudes towards HIV infected people, and c) pill use at last sexual intercourse. Nevertheless, regarding sexual intercourse, age of first sexual intercourse and condom use results were confounded by the control variables. Due to space reasons the results of these analyses weren't presented here. 
Table 4. Differences between 2002, 2006 and 2010 for attitudes towards HIVinfected people for the total sample.

\begin{tabular}{|c|c|c|c|c|c|c|c|c|c|c|c|}
\hline & \multicolumn{2}{|c|}{2002} & \multicolumn{2}{|c|}{2006} & \multicolumn{2}{|c|}{2010} & \multicolumn{2}{|c|}{ Total $^{1}$} & \multirow{2}{*}{$\chi^{2}$} & \multirow{2}{*}{\multicolumn{2}{|c|}{$p$}} \\
\hline & $\mathbf{N}$ & $\%$ & N & $\%$ & N & $\%$ & $N$ & $\%$ & & & \\
\hline $\begin{array}{l}\text { I wouldn't be } \\
\text { a friend of } \\
\text { someone if he } \\
\text { had AIDS }\end{array}$ & & & & & & & & & 13.461 & & 0.009 \\
\hline Agree & 226 & 6.1 & 222 & 7.0 & 235 & 7.5 & 683 & 6.8 & & & \\
\hline I'm not sure & 629 & 17.0 & 588 & 18.5 & 608 & 19.3 & 1825 & 18.2 & & & \\
\hline Disagree & 2852 & 76.9 & 2366 & 74.5 & 2308 & 73.2 & 7526 & 75.0 & & & \\
\hline $\begin{array}{l}\text { Adolescents } \\
\text { with AIDS } \\
\text { should be } \\
\text { allowed to go to } \\
\text { school }\end{array}$ & & & & & & & & & 72.083 & & 0.000 \\
\hline Agree & 2586 & 70.1 & 2188 & 69.3 & 1928 & 61.3 & 6702 & 67.1 & & & \\
\hline I'm not sure & 644 & 17.5 & 550 & 17.4 & 727 & 23.1 & 1921 & 19.2 & & & \\
\hline Disagree & 457 & 12.4 & 418 & 13.2 & 489 & 15.6 & 1364 & 13.7 & & & \\
\hline $\begin{array}{l}\text { I would sit near } \\
\text { an infected } \\
\text { student in the } \\
\text { classroom }\end{array}$ & & & & & & & & & 117.797 & & 0.000 \\
\hline Agree & 2615 & 70.8 & 2106 & 66.6 & 1835 & 58.4 & 6556 & 65.6 & & & \\
\hline I'm not sure & 775 & 21.0 & 749 & 23.7 & 927 & 29.5 & 2451 & 24.5 & & & \\
\hline Disagree & 305 & 8.3 & 309 & 9.8 & 381 & 12.1 & 995 & 10.0 & & & \\
\hline $\begin{array}{l}\text { I would visit a } \\
\text { friend if he or } \\
\text { she had AIDS }\end{array}$ & & & & & & & & & 201.713 & & 0.000 \\
\hline Agree & 3104 & 83.9 & 2540 & 80.6 & 2206 & 70.1 & 7850 & 78.5 & & & \\
\hline I'm not sure & 425 & 11.5 & 444 & 14.1 & 667 & 21.2 & 1536 & 15.4 & & & \\
\hline Disagree & 172 & 4.6 & 169 & 5.4 & 272 & 8.6 & 613 & 6.1 & & & \\
\hline $\begin{array}{l}\text { HIV infected } \\
\text { people should } \\
\text { live apart of the } \\
\text { rest of people }\end{array}$ & & & & & & & & & 144.506 & & 0.000 \\
\hline Agree & 294 & 8.0 & 293 & 9.3 & 330 & 10.5 & 917 & 9.2 & & & \\
\hline I'm not sure & 300 & 8.1 & 314 & 9.9 & 509 & 16.3 & 1123 & 11.2 & & & \\
\hline Disagree & 3103 & 83.9 & 2551 & 80.8 & 2293 & 73.2 & 7947 & 79.6 & & & \\
\hline & & 02 & & & 2010 & & Total & & & & Scheffe \\
\hline & M & SD & M & SD & $M$ & SD & M & $S D$ & $\mathrm{~F}$ & $p$ & post hocs ${ }^{2}$ \\
\hline Total scale & 13.47 & 2.02 & 13.28 & 2.13 & 12.84 & 2.24 & 13.21 & 2.14 & 76.815 & 0.000 & $a<b<c$ \\
\hline
\end{tabular}

\section{Discussion}

The goal of this study was to document recent trends in preventive sexual behaviors in Portuguese adolescents, including information and attitudes about HIV/AIDS, and assessing whether they have changed and how they have changed from 2002 to 2010.

In terms of preventive behaviors, results showed that in 2010, on average $78.2 \%(n=7924)$ of 8 th and 10th grade adolescents have not had sexual intercourse. Comparing the data from the 2002, 
2006 and 2010 HBSC surveys, results showed an increasing trend regarding the percentage reporting first sexual intercourse at 14 years old or more and condom use at last sexual intercourse (even though the explanation may rely partially on gender, age or school grade) and a stabilized trend regarding having had sexual intercourse and contraceptive pill use at last sexual intercourse.

In terms of information and attitudes about HIV/AIDS, results showed that in 2010 on average 8 th and 10th grade adolescents are well information and have moderately tolerant attitudes towards people with HIV/AIDS. Comparing the data from the 2002, 2006 and 2010 HBSC surveys results showed a systematic decreasing trend.

Therefore, on the one hand, there's an improvement on sexual reproductive health because in 2010 preventive behaviors have either increased or stabilized, which means that there was a bigger chance adolescents could be better informed and motivated, and have better behavioral skills than in 2002 and 2006. Moreover, since age of first sexual intercourse is stabilizing at 14 or more, it seems that adolescents are not anticipating their sexual debut, probably because of all the HIV/AIDS campaigns and structured sex education being implemented in Portugal.

On the other hand, some aspects of sexual reproductive health caused some concern: the systematic reduction of information regarding HIV/AIDS transmission / prevention, and decrease in tolerant attitudes towards people with HIV/AIDS. Though in general, adolescents were well informed about the main HIV/AIDS transmission routes and how to protect themselves from becoming infected, their information decreased and a minority still lacked information about main issues. This conclusion reinforced findings from other studies in this area (Currie, Hurrelmann, Settertobulte, Smith, \& Todd, 2000; Eurostat, 2012). In 2010, 13.5\% believed the oral contraceptive could protect against HIV/AIDS infection. This may be the reason why some of them haven't used a condom during last sexual intercourse and, unfortunately, why the incidence of HIV/AIDS continues to be so significant in this age group.

And $18.3 \%$ (in 2010 compared to $8.6 \%$ in 2006 and $7.0 \%$ in 2002) didn't know it is possible to become infected with HIV/AIDS by engaging in unprotected sexual intercourse with someone just once. Though most adolescents admitted knowing that it is possible for a person to have intercourse without a condom once and get infected with HIV/AIDS, it seems that quite a few students may be underestimating the risk in the sense that their risk perception is not consistent with their reports of involvement in potentially risky behaviors such as not having used condom during the last sexual intercourse.

In relation to the percentage reporting condom use during last sexual intercourse, it is important to refer that still about $18 \%$ are not using it and thus continue engaging in sex risk behaviors.

There is a residual group of adolescents who engage in unprotected or poorly protected sexual activity. It is imperative to find out why the message doesn't get through to these adolescents and what their particular characteristics are, so that prevention interventions become more successful with this group.

As for the decrease in tolerant attitudes towards people with HIV/AIDS, it is important to say that, in general, respondents did show positive attitudes, they were tolerant and inclusive. Nonetheless, there was a general decrease in their tolerant attitudes, which must be analyzed, mainly because it was not the only area they have shown a setback.

Some authors (Matos, 2008) believe that a few adolescents are no longer concerned about being well informed on prevention and transmission of HIV/AIDS, as long as they use a condom. In this sense they may not be so concerned either about being tolerant towards HIV infected people, they may see it as the consequence of their own irresponsibility, lacking the capacity to consider that condoms aren't $100 \%$ effective, so even using a condom at every sexual intercourse there's a chance of becoming infected for condoms can break, tare and slip off.

The results showed a gap between what young people knew about HIV/AIDS and what they expressed in sexual behavior. Thus, we can say that is not information per se, although it is a major prerequisite, which will implement the behavioral changes. Several studies have emphasized the relativization of the amount of information about HIV/AIDS, both regarding preventive behavioral strategies and decision making about personal risk of infection (Matos, 2008; UNAIDS, 2009). 


\section{Conclusions}

Overall, young people have more preventive sexual behaviors (have their first sexual intercourse older and use condom and contraceptive pill at their last sexual intercourse) than before. Nevertheless, there is still a residual group of about $18 \%$ of adolescents among those sexually active who engage in unprotected or poorly protected sexual activity. Also, a reduction of information regarding HIV/AIDS transmission/prevention and of positive attitudes towards people with HIV/AIDS was observed.

With what the perception of vulnerability is concerned, young people continue to underestimate the risk mainly because of the sense of invulnerability among heterosexuals in general and the social representation of the illness onset (DiClemente, Forrest, \& Mickler, 1990). Moreover, adolescents' typical egocentrism also translates into difficulties in realizing their vulnerability (Boruchovitch, 1992).

The analyses suggested that formal sex education in school context promotes protective sexual behaviors, but there is still a lot to be done since not all adolescents refer having protective behaviors and that can bring major negative outcomes in terms of public health (Ramiro, Reis, Matos, Diniz, \& Simões, 2011). Besides, though adolescents seemed to have focused on preventive behaviors, they seemed to have disregarded information and attitudes in general. This suggested that sex education programs implemented in Portugal are still too limited to teaching sessions, strongly homogenized in their content and consequently inadequate to enhance the level of information and attitudes regarding HIV, let alone personal and social skills of different target groups.

HIV prevention school-based programs have been suggested (Basen-Engquist, et al., 1997; Thurman, 2000) as a means of effective universal access when targeting adolescents. Schools present a valuable setting because that's where nearly all adolescents spend a significant part of their time; it possesses educational structures and resources that will favor the integration of the HIV theme in the context of sexual health education programs (Diclemente et al., 2000). However, research emphasizes that few programs achieve positive results. This is probably due to the lack of a theory at the base of the intervention program (Fisher, \& Fisher, 2000).

Since 1986, sex education in Portugal has been compulsory in elementary and middle school and from 2010 onwards in high school too. Moreover, a group of specialists (GTES, 2007) hired by the Portuguese Ministry of Education produced specific legislation and established support measures for the implementation of sex education in school context. Though the government has done a great effort to regulate all necessary aspects and published a conceptual framework for sex education, not all schools comply with the Portuguese Ministry of Education guidelines just yet.

Moreover, there isn't a program of intervention based on a specific theory as studies show it should (Kirby, Laris, \& Rolleri, 2007). National guidelines indicate teachers should improve adolescents' information, not only regarding HIV/AIDS transmission and prevention but also to clarify myths and misconceptions, work on their attitudes, and motivation to condom use, as well as develop their personal and social skills, which are somehow similar to the IMB model (Information, Motivation and Behavior model). But it is necessary that the IMB model, which has demonstrated intervention efficacy, is clearly adopted, i.e., identified, explained and then applied and evaluated in Portuguese schools.

The findings of this study must be considered in light of the study's strengths and limitations. The HBSC provides the ability to assess trends through repeated measurements at several frequently spaced points in time, thereby providing a unique opportunity to examine trends. Nevertheless, it relies on self-reported measures and recall bias. Also, the questionnaire doesn't contemplate measures about adolescents' motivation and behavioral skills that are part of the IBM model (Fisher, \& Fisher, 1992; 1993), so not all variables of the IBM model were assessed.

The authors of this research do not intend to advocate abstinence-only programs. Evidence does not indicate that abstinence-only interventions effectively decrease risk among adolescents (Kohler, Manhart, \& Lafferty, 2008; Underhill, Operario, \& Montgomery, 2011).

Future research should investigate the prevalence of evidence-based programs used in formal 
settings as well as determine their effectiveness when implemented on a large scale. There is also a need to better understand the process of scaling up the implementation of evidence-based programs (Ramiro, Reis, Matos, Diniz, \& Simões, 2011).

As a final note, it's important to emphasize adolescents' increasing ability to adopt preventive behaviors, therefore findings are promising.

\section{Acknowledgements}

The first author has a scholarship from the Foundation of Science and Technology with the reference: SFRH/BD/43388/2008.

\section{References}

Bandura, A. (1989). Perceived self-efficacy in the exercise of control over AIDS infection. In Mays, V., Albee, G. \&. Schneider, S. (Eds.), Primary prevention of AIDS (pp. 128-141). Newbury Park, CA: Sage.

Bandura, A. (1994). Social cognitive theory and exercise of control over HIV infection. In DiClemente, R. \& Peterson, J. (Eds.), Preventing AIDS: Theories and methods of behavioral interventions (pp. 25-59). New York: Plenum.

Basen-Engquist, K., Parcel, G., Harrist, R., Kirby, D., Coyle, K., Banspach, S., \& Rugg, D. (1997). The Safer Choices Project: Methodological issues in school-based health promotion intervention research. Journal of School Health, 67, 365-371.

Belo, M., \& Silva, J. (2004). Knowledge, attitudes, and practices on previous use of contraceptive methods among pregnant teenagers. Revista de Saúde Pública, 38 (4), 479-487.

Boruchovitch, E. (1992). Factores associados a não-utilização de anticoncepcionais na adolescência. [Factors associated to non use of contraceptive methods in adolescence.] Revista de Saúde Pública, $26(6), 137-443$

Centers for Disease Control and Prevention. (2010). Youth Risk Behavior Surveillance - United States, 2009: Surveillance Summaries. Department of Health and Human Services. MMWR, 59.

Currie C., Hurrelmann K., Settertobulte W., Smith R., \& Todd J. (2000). Health and health behavior among young people. Copenhagen: World Health Organization.

Currie, C., Samdal, O., Boyce, W., \& Smith, R. (2001). HBSC, a WHO cross national study: research protocol for the 2001/2002 survey. Copenhagen: WHO.

Currie, C., Zanotti, C., Morgan, A., Currie, D., de Looze, M., Roberts, C., Samdal, O., Smith, O., \& Barnekow, V. (Eds). (2012). Social Determinants of health and well-being among young people. Health Behaviour in School-aged Children (HBSC) study: international report from the 2009/2010 survey. In: WHO policy series: Health Policy for Children and Adolescents. Copenhagen: WHO Regional Office for Europe.

CVEDT - Centro de Vigilância das Doenças Sexualmente Transmissíveis. Infecção VIH /SIDA. (2011). A situação em Portugal a 31 de Dezembro de 2010. [HIV/AIDS. (2011). The situation in Portugal on December 31, 2010]. Lisboa: INSA.

Diclemente R., Wingood G., Crosby R., Sionean, C., Brown, L., Rothbaum, B., Zimand, E., Cobb, B., Harrington, K., \& Davies, S. (2000). Prospective study of psychological distress and sexual risk behavior among black adolescent females. Pediatrics, 108, 1-6.

DiClemente, R., Forrest, K., \& Mickler, S. (1990). College student's knowledge and attitudes about AIDS and changes in VIH - Preventive behaviors. AIDS Education and Prevention, 2, 201-212.

Eurostat. População e Condições de trabalho - Demografia. [European Statistics] 2012. Retrieved 21/03/2013 from: http://epp.eurostat.ec.europa.eu/statistics_explained/index.php/Employment_statistics

Fisher, J., \& Fisher, W. (1992). Changing AIDS risk behavior. Psychological Bulletin, 111, 455-474. 
Fisher, J., \& Fisher, W. (2000). Theoretical approaches to individual-level change in HIV risk behavior. In Peterson, J. \& DiClemente, R. (Eds.), HIV prevention handbook (pp. 3-55). New York: Plenum.

Fisher, W., \& Fisher, J. (1993). Understanding and promoting AIDS preventive behavior: A conceptual model and educational tools. The Canadian Journal of Human Sexuality, 1, 99-106.

GTES - Grupo de trabalho de educação sexual/educação para a saúde; Sampaio D. (Coord.); Baptista, I., Matos, M. G., Silva, M. O. (2007). Relatório final. [Final Report.] Direcção-Geral de Inovação e de Desenvolvimento Curricular. Ministério da Educação.

Kirby, D., Laris, B. A., \& Rolleri, L. (2007). Sex and HIV education programs: Their impact on sexual behaviors of young people throughout the world. Journal of Adolescent Health, 40, 206-217.

Kohler, P., Manhart, L., \& Lafferty, W. (2008). Abstinence-Only and Comprehensive Sex Education and the Initiation of Sexual Activity and Teen Pregnancy. Journal of Adolescent Health, 42, 344-351.

Matos, M. (2003). A Saúde dos adolescentes portugueses (quatro anos depois). [The health of Portuguese adolescents - four years after.] Lisboa: Edições FMH.

Matos, M. G., Simões, C., Tomé, G., Gaspar, T., Camacho, I., Diniz, J. A., et al. (2006). A saúde dos adolescentes portugueses: Hoje e em 8 anos, 2006. [The Health of Portuguese adolescents - Today and in 8 years, 2006.] Retrieved 05/12/2012 from http://www.fmh.utl.pt/aventurasocial/pdf/191206/ nacional.pdf

Matos, M. G. (Ed). (2008). Sexualidade, Segurança e SIDA. [Sexuality, Safety and AIDS.] Lisboa: IHMT/FMH/FCT.

Matos, M. G., Simões, C., Tomé, G., Camacho, I., Ferreira, M., Ramiro, L., Reis, M., \& Equipa Aventura Social (2011). A Saúde dos Adolescentes Portugueses - Relatório do Estudo HBSC 2010. [The Health of Portuguese adolescents - HBSC Study Report 2010.] ACS/FMH/UTL/CMDT-UNL.

Ministério da Educação - Lista nacional de escolas do ministério da educação. Retrieved 20/03/2013 from http://www.lerportugues.net $/ \mathrm{np} 4 / \% 7 \mathrm{~B} \% 24$ clientServletPath $\% 7 \mathrm{D} /$ ?newsId $=11 \&$ fileName $=1 \mathrm{i}$ sta_es_publicas.pdf

Ramiro, L., Reis, M., Matos, M. G., Diniz, J., \& Simões, C. (2011). Educação Sexual, Conhecimentos, Crenças, Atitudes e Comportamentos nos adolescentes. [Sexual Education, Knowledge, Beliefs, Attitudes and Behaviors among adolescents.] Revista Portuguesa de Saúde Pública, 29 (1), 11-21.

Roberts, C., Freeman, J., Samdal, O., Schnohr, C., De Looze, M., Nic Gabhainn, S., et al. (2009). The Health Behaviour in School-aged Children (HBSC) study: methodological developments and current tensions. International Journal of Public Health, 54, 140-150.

Synovitz, L., Herbert, E., Kelley, R., \& Carlson, G. (2002). Sexual knowledge of college students in a southern state: relationship to sexuality education results of Louisianna college student study shows need for sexuality programs. American Journal of Health Studies. Retrieved 19/02/2013 from www.findarticles.com

Thurman, S. (2000, October). Youth and HIV/AIDS 2000: A new American agenda. A message from the Director of National AIDS Policy. In The body: An AIDS and HIV information resource. Retrieved 19/02/2013 from http://www.thebody.com/whitehouse/youthreport/director.html

UNAIDS (2008). Joint United Nations Programme on HIV/AIDS. Report on the global HIV/AIDS epidemic. Joint United Nations Programme on HIV/Aids. WHO Library Catalogue-in-Publication Data.

UNAIDS (2009). Joint United Nations Programme on HIV/AIDS. Report on the global HIV/AIDS epidemic. Joint United Nations Programme on HIV/Aids. WHO Library Catalogue-in-Publication Data.

UNAIDS (2010). Global Report: UNAIDS report on the Global Aids epidemic 2010. Joint United Nations Programme on HIV/Aids. WHO Library Catalogue-in-Publication Data.

UNAIDS (2011). Joint United Nations Programme on HIV/AIDS. Report on the global HIV/AIDS epidemic. Joint United Nations Programme on HIV/Aids. WHO Library Catalogue-in-Publication Data.

Underhill, K., Operario, D., \& Montgomery, P. (2011). Abstinence-only programs for HIV infection prevention in high-income countries: Systematic Reviews. Cochrane Database of Systematic Reviews, 4. Retrieved 20/03/2013 from http://www.health-evidence.ca/articles/show/20966

UNFPA - United Nations Population Fund (2005). The state of world population 2005 -The unmapped 
journey: Adolescents, Poverty and Gender. New York: UNFPA. Retrieved 20/03/2013 from: http:// www.unfpa.org/swp/2005/english/ch5/index.htm

WHO (2010). Position paper on mainstreaming adolescent pregnancy in efforts to make pregnancy safer. Department of Making Pregnancy Safer. WHO Document Production Services, Geneva, Switzerland.

Advised by Guna Svence,

Riga Teacher Training and Educational Management Academy, Latvia

Received: January 31, 2013

Accepted: March 22, 2013

Lúcia Ramiro PhD Student, Teacher, Technical University of Lisbon, CMDT \& Aventura Social Project, Estrada da Costa - Cruz Quebrada, Portugal.

E-mail: lisramiro@sapo.pt

Website: www.aventurasocial.com

\footnotetext{
Margarida Gaspar de Matos

PhD, Full Professor, Clinical and Health Psychologist, Technical University of Lisbon (UTL), CMDT \& Aventura Social Project, Estrada da Costa - Cruz Quebrada, Portugal.

E-mail: mmatos@fmh.utl.pt

Website: www.aventurasocial.com

Marta Reis PhD, Clinical and Health Psychologist, Technical University of Lisbon (UTL), CMDT \& Aventura Social Project, Estrada da Costa - Cruz Quebrada, Portugal.

E-mail: reispsmarta@gmail.com

Website: www.aventurasocial.com
} 